KONSTRUKTIVISME, Vol. 7, No. 2, Juli 2015

p-ISSN: 1979-9438, e-ISSN: 2445-2355

FKIP Universitas IslamBalitar,Blitar

Web: konstruktivisme.unisbablitar.ejournal.web.id

\title{
PENGARUH GAYA KEPEMIMPINAN KEPALA SEKOLAH \\ DAN MOTIVASI KERJA TERHADAP KINERJA GURU \\ DI MA MA'ARIF SELOREJO BLITAR
}

\author{
Muhammad lqbal Baihaqi \\ Madrasah Aliyah Ma'arif Selorejo Blitar \\ Email: iqbal_baihaqi123@yahoo.co.id
}

\begin{abstract}
The objectives of this study are to see the effect of: principal leadership, performance motivation, and principal leadership and performance motivation toward teacher' performance. The study used correlationl design involving 23 teachers as sample. Instruent used for the study is questionnaire. The study found the following findings. Descriptive statistic showed that three aspects being investigated are good, in terms of principal leadership, teacher competence, and teachers' performance. Results of hypothesis testing showed that significant effect was contributed in terms of (1) principal leadership toward teacher's performance $(r=2.599$, $\mathrm{p}=0.05)$, (2) performance motivation towards teacher performance $(r=3.160, p=0.05)$, and (3) leadership and performance motivation towards teacher performance $(F=8.48, p=0.05)$.
\end{abstract}

Key-words: performance, leadership, performance motivation.

\section{Abstrak}

Tujuan penelitian ini adalah untuk menganalisis pengaruh kepemimpinan kepala sekolah terhadap kinerja guru, pengaruh motivasi kerja guru terhadap kinerja guru, dan kepemimpinan kepala sekolah dan motivasi kerja dengan kinerja guru. Penelitian menggunakan rancangan korelasi dengan melibatkan 23 guru MA Ma'arif Selorejo Blitar. Instrumen penelitian ialah angket. Data dianalisis menggunakan statistik deskriptif dan regresi. Hasil uji statistik deskriptif menunjukkan bahwa (1) kepemimpinan kepala sekolah di MA Ma'arif Selorejo masuk dalam kategori baik, (2) kompetensi guru MA Maarif berkatagori baik, dan (3) kinerja guru MA Maarif berkatagori baik. Uji hipotesis terhadap tiga variable menunukkan: (1) Kepemimpinan kepala sekolah berpengaruh signifikan terhadap kinerja guru ( $r=2.599, p=0.05)$; (2) Motivasi kinerja guru berpengaruh signifikan pada kinerja guru $(r=3.160$, $\mathrm{p}=0.05)$, dan (3) Kepemimpinan dan motivasi kerja berpengaruh signifikan terhadap kinerja guru $(F=8.48, p=0.05)$.

Kata-Kunci: kinerja, kepemimpinan, motivasi kerja. 
p-ISSN: 1979-9438, e-ISSN: 2445-2355

FKIP Universitas Islam Balitar, Blita

Web: konstruktivisme.unisbablitar.ejournal.web.id

Kinerja guru merupakan kemampuan seorang guru dalam melaksanakan tugas pembelajaran di sekolah atau madrasah dan bertanggung jawab peserta didik di bawah bimbingannya dengan meningkatkan prestasi belajar peserta didik oleh karena itu kinerja guru itu dapat di artikan sebagai suatu kondisi yang menunjukkan kemampuan seorang guru dalam menjalankan tugasnya di sekolah atau madrasah serta menggambarkan adanya suatu perbuatan yang di tampilkan guru dalam melakukan aktifitas pembelajaran. Peningkatan terhadap kinerja guru di sekolah perlu di lakukan baik oleh guru sendiri yaitu melalui motivasi yang di milikinya maupun dari kepala sekolah melalui kepemimpinan dan pembinaannya. Gaya kepemimpinan merupakan norma perilaku yang dipergunakan oleh seseorang pada saat orang tersebut mencoba mempengaruhi perilaku orang lain. Gaya kepemimpinan banyak mempengaruhi keberhasilan seorang pemimpin dalam mempengaruhi perilaku bawahannya. Kepemimpinan suatu organisasi perlu mengembangkan staf dan membangun iklim motivasi yang menghasilkan tingkat produktivitas yang tinggi. Movivasi guru juga berkaitan dengan kinerja guru. Guru memiliki posisi yang sangat menentukan keberhasilan pembelajaran dalam merancang, mengelola, melaksanakan, dan mengevaluasi pembelajaran. Motivasi guru juga berperan aktif dalam pengembangan sekolah terutama di MA Ma'arif Selorejo yang merupakan madrasah Aliah swasta di wilayah selorejo kabupaten Blitar. Peningkatan kinerja guru di MA Ma'arif Selorejo masih belum optimal sehingga perlu di lakukan peningkatan dan cara-cara untuk meningkatkan kinerja guru salah satunya dapat dilakukan oleh guru sendiri yaitu melalui motivasi yang di milikinya maupun dari kepala sekolah melalui kepemimpinan dan pembinaannya. Pengaruh antara gaya kepemimpinan kepala sekolah dan motivasi kerja dalam meningkatkan kinerja guru perlu diteliti lebih mendalam oleh karena itu peneliti tertarik untuk meneliti tentang Pengaruh Gaya Kepemimpinan Kepala Sekolah dan Motivasi Kerja Terhadap Kinerja Guru di MA Ma'arif Selorejo Blitar.

Rumusan masalah penelitian ini adalah: 1) Apakah terdapat pengaruh kepemimpinan kepala sekolah terhadap kinerja guru di MA Ma'arif Selorejo Blitar. 2) Apakah terdapat pengaruh motivasi kerja guru terhadap kinerja guru di MA Ma'arif Selorejo Blitar. 3) Apakah terdapat pengaruh kepemimpinan kepala sekolah dan motivasi kerja guru terhadap kinerja guru di MA Ma'arif Selorejo Blitar.

Tujuan penelitian ini adalah: 1) Menganalisis pengaruh kepemimpinan kepala sekolah terhadap kinerja guru di MA Ma'arif Selorejo Blitar. 2) Menganalisis pengaruh motivasi kerja guru terhadap kinerja guru di MA Ma'arif Selorejo Blitar. 3) Menganalisis pengaruh kepemimpinan kepala sekolah dan motivasi kerja dengan kinerja guru di MA Ma'arif Selorejo Blitar.

Menurut istilah kepemimpinan adalah proses mempengaruhi aktivitas individu atau kelompok untuk mencapai tujuan-tujuan tertentu dalam situasi yang telah ditetapkan. Dalam mempengaruhi aktifitasnya individu pemimpin menggunakan kekuasaan, kewenangan, pengaruh, sifat 
Baihaqi, I. Muhammad. 2015. Pengaruh Gaya Kepemimpinan Kepala Sekolah dan Motivasi Kerja Terhadap Kinerja Guru di MA Ma'arif Selorejo Blitar. Konstruktivisme, 7(2): 97-106.

dan karakteristik, dan Tujuannya adalah untuk meningkatkan produktivitas dan moral kelompok.

Pakar manageman pendidikan seperti Hendyat Soetopo dalam konklusinya memberikan batasan definisi kepemimpinan sebagai proses mempengaruhi, mengarahkan, dan mengoordinasikan segala kegiatan organisasi atau kelompok untuk mencapai tujuan organisasi dan kelompok.

Sedangkan Stephen P.Robbins mendeskripsikan Kepemimpinan adalah Kemampuan mempengaruhi suatu kelompok ke arah pencapaian tujuan.Ada juga pendapat yang cukup menarik untuk di telaah yaitu dari D. Katz dan R.L. Kahn yang menyatakan bahwa kepemimpinan adalah peningkatan pengaruh sedikit demi sedikit pada dan berada di atas kepatuhan mekanis terhadap pengarahan-pengarahan rutin organisasi.

Macam-macam gaya kepemimpinan adalah: 1) Tipe Otokrasi/ Otoriter yaitu Pemerintahan atau kekuasaan yang dipegang oleh seseorang yang berkuasa secara penuh dan tidak terbatas masanya. Sedangkan yang memegang kekuasaan disebut otokrat yang biasanya dijabat oleh pemimpin yang berstatus sebagai raja atau yang menggunakan sistem kerajaan. 2) Tipe Laissez-Faire yaitu Kepala sekolah sebagai pemimpin bertipe laissez faire menghendaki semua komponen pelaku pendidikan menjalankan tugasnya dengan bebas. 3) Tipe Demokratis Kepemimpinan demokratis adalah kepemimpinan berdasarkan demokrasi yang pelaksanaannya disebut pemimpin partisipasi (partisipative leadership). Kepemimpinan partisipasi adalah suatu cara pemimpin yang kekuatannya terletak pada partisipasi aktif dari setiap warga kelompok.

Istilah Motivasi (Motivation) berasal dari bahasa latin, yakni movere, yang berarti "menggerakkan". Motivasi merupakan kondisi atau energi yang menggerakkan diri karyawan yang terarah atau tertuju untuk mecapai tujuan organisasi. Motivasi adalah usaha pemberian dorongan pada seseorang agar mau bertindak dengan cara yang diinginkan dalam mencapai tujuan yang diharapkan.

Faktor-faktor yang mendorong seseorang guru untuk melakukan pekerjaannya secara lebih bersemangat sehingga akan memperoleh prestasi yang lebih baik. Faktor-faktor tersebut antara lain: 1) Faktor intrinsik yaitu faktor-faktor yang timbul dari dirinya sendiri. indikator intrinsik yaitu: Keinginan untuk berprestasi, Keinginan untuk maju, Pemberian tanggung jawab (responsibility). 2) Faktor ekstrinsik, yaitu faktor dari luar, disini seorang guru yang akan mempengaruhi semangatnya dalam bekerja. Indikator ekstrinsik yaitu: Pekerjaan itu sendiri atau pekerjaan guru tersebut, Lingkungan kerja Keamanan, Gaji atau penghasilan, Pengakuan dan penghargaan, Kepercayaan, Kebijakan pimpinan

Kinerja guru merupakan kemampuan seorang guru dalam melaksanakan tugas pembelajaran di sekolah atau madrasah dan bertanggung jawab peserta didik di bawah bimbingannya dengan meningkatkan prestasi belajar peserta didik. Kinerja guru itu dapat di artikan sebagai suatu kondisi yang menunjukkan kemampuan seorang guru dalam menjalankan tugasnya di sekolah atau madrasah serta 
menggambarkan adanya suatu perbuatan yang di tampilkan guru dalam melakukan aktifitas pembelajaran.

Kinerja guru merupakan kemampuan seorang guru dalam melaksanakan tugas pembelajaran di sekolah atau madrasah dan bertanggung jawab peserta didik di bawah bimbingannya dengan meningkatkan prestasi belajar peserta didik. Kinerja guru itu dapat di artikan sebagai suatu kondisi yang menunjukkan kemampuan seorang guru dalam menjalankan tugasnya di sekolah atau madrasah serta menggambarkan adanya suatu perbuatan yang di tampilkan guru dalam melakukan aktifitas pembelajaran.

Kinerja guru dapat di tunjukkan dari kompetensi yang harus di penuhi yaitu kompetensi pedagogik, kepribadian, sosial dan kompetensi profesional. Pendidik harus memiliki kualifikasi akademik dan kompetensi sebagai agen pembelajaran, sehat jasmani dan rohani, serta memiliki kemampuan untuk mewujudkan tujuan pendidikan nasional.

Kualifikasi akademik yang dimaksudkan di atas adalah tingkat pendidikan minimal yang harus dipenuhi oleh seorang pendidik yang dibuktikan dengan ijazah dan/atau sertifikat keahlian yang relevan sesuai ketentuan perundang-undangan yang berlaku. Kompetensi sebagai agen pembelajaran pada jenjang pendidikan dasar dan menengah serta pendidikan anak usia dini meliputi: Kompetensi pedagogik, Kompetensi kepribadian, Kompetensi sosial dan Kompetensi professional.

Pola kepemimpinan kepala sekolah juga berpengaruh dalam meningkatkan kinerja guru. Kepemimpinan dibidang pendidikan merupakan pemimpin yang harus memiliki keterampilan dalam mempengaruhi, mendorong, membimbing, mengarahkan, dan menggerakkan orang lain yang ada hubungannya dengan pelaksanaan dan pengembangan pendidikan dan pengajaran ataupun pelatihan agar segenap kegiatan dapat berjalan secara efektif dan efisien yang pada gilirannya akan mencapai tujuan peningkatan kinerja guru dan tujuan pendidikan yang telah ditetapkan.

Dalam penelitian ini yang berjudul "Pengaruh Gaya kepemimpinan Kepala Sekolah dan Motivasi kerja guru terhadap kinerja guru" ini di dalamnya terdapat dua variabel independen dan satu dependen sehingga merupakan paradigma ganda dengan dua variabel independen X1 dan X2, dan satu variabel dependen $Y$. Variabel dalam penelitian ini meliputi:1) Variabel bebas (independen): kepemimpinan kepala sekolah (X1) dan Motivasi kerja(X2). 2) Variabel terikat (dependent): Kinerja Guru (Y).

\section{METODE}

Penelitian ini berusaha mendeskripsikan pengaruh gaya kepemimpinan kepala madrasah dan motivasi guru terhadap kinerja guru MA Ma'arif Selorejo Blitar. Maka peneliti mengunakan jenis penelitian kuantitatif. Penelitian kuantitatif adalah metode penelitian yang berlandaskan pada filsafat positivisme digunakan untuk meneliti pada populasi dan sampel tertentu, teknik pengambilan sampel pada umumnya dilakukan secara random, pengumpulan data menggunakan instrumen 
Baihaqi, I. Muhammad. 2015. Pengaruh Gaya Kepemimpinan Kepala Sekolah dan Motivasi Kerja Terhadap Kinerja Guru di MA Ma'arif Selorejo Blitar. Konstruktivisme, 7(2): 97-106.

penelitian, analisis data bersifat kuantitatif atau statistik dengan tujuan untuk menguji hipotesis yang telah ditetapkan

Populasi adalah semua obyek atau individu yang memiliki karakteristik tertentu, jelas, dan lengkap yang akan diteliti. Dari definisi tersebut maka populasi dalam penelitian ini adalah guru yang ada di lingkungan MA Ma'arif Selorejo yaitu sejumlah 23 Guru.

Sampel adalah bagian dari jumlah dan karakteristik yang dimiliki oleh populasi. Dalam hal ini sampel haruslah representatif dan mampu mewakili semua jumlah populasi yang ada. Teknik sampel yang digunakan yaitu random sampling yaitu teknik penentuan sampel dengan acak. Dalam penelitian ini pertimbangan dengan kriteria guru yang mengajar di MA Ma'arif Selorejo Blitar.

Metode yang digunakan penulis adalah: dokumentasi dan metode angket (quesional) untuk mengetahui pengaruh gaya kepemimpinan kepala sekolah dan motivasi kerja terhadap kinerja guru di MA Ma'arif Selorejo Blitar baik secara parsial maupun simultan maka perlu diadakan analisis data. Analisi data dalam penelitian ini menggunakan Uji normalitas data, Uji Asumsi Klasik Regresi Berganda, Teknik Regresi Berganda sehingga akan diketahui apakah ada pengaruh variabel $\mathrm{XI}$ terhadap $\mathrm{Y}$, variabel $\mathrm{X} 2$ terhadap $\mathrm{Y}$, dan secara bersama-sama pengaruh variabel $\mathrm{XI}$ dan $\mathrm{X} 2$ terhadap variabel $\mathrm{Y}$.

\section{HASIL DAN BAHASAN}

Variabel kepemimpinan kepala sekolah dijaring melalui angket tentang gaya kepemimpinan kepala sekolah mencakup 12 indikator dengan 13 pertanyaan dan skor 1-4. Hasil pengolahan statistik deskriptif diketahui bahwa kompetensi guru meliputi: kurang baik $3(13,04 \%)$, cukup $1(4,35 \%)$, baik $16(69,57 \%)$, dan sangat baik 3 (13,04\%). Secara umum dapat dinyatakan bahwa kepemimpinan kepala sekolah di MA Ma'arif Selorejo masuk dalam kategori baik.

Variabel motivasi kerja guru diukur menggunakan indikator sebagai berikut: keinginan untuk berprestasi, keinginan untuk maju, lingkungan kerja, rasa aman, Indikator-indikator tersebut dibuat 11 pertanyaan dengan skor 1-4 dari setiap pertanyaan. Hasil pengolahan statistik deskriptif diketahui bahwa kompetensi guru adalah: kurang 2 (8,70\%), cukup 5 $(21,74 \%)$, baik $11(47,82 \%)$, dan sangat baik $5(21,74 \%)$. Secara umum dapat dinyatakan bahwa kompetensi guru di MA Ma'arif masuk dalam kategori baik.

Variabel kinerja guru diukur dengan menggunakan nilai APKG. Hasil pengolahan statistik deskriptif diketahui bahwa kinerja guru ialah: kurang $0(0 \%)$, cukup $7(30,43 \%)$, baik $10(43,48 \%)$, dan amat baik 6 $(26,09 \%)$. Secara umum dapat dinyatakan bahwa kinerja guru di MA Ma'arif masuk dalam kategori baik.

Pengaruh Gaya Kepemimpinan Kepala Sekolah terhadap Kinerja Guru yang dilakukan secara parsial menunjukkan bahwa terdapat pengaruh antara Gaya Kepmimpinan (x1) terhadap kinerja guru (y). Disimpulkan bahwa gaya kepemimpinan kepala sekolah berpengaruh 
secara positif terhadap kinerja guru, artinya apabila tingkat gaya kepemimpinan kepala sekolah mengalami kenaikan maka kinerja guru di MA Ma'arif Selorejo juga mengalami kenaikan. Sebaliknya apabila gaya kepemimpinan kepala sekolah menurun maka kinerja guru di MA Ma'arif Selorejo menurun dan dimpulkan bahwa ada pengaruh yang signifikan dan positif antara Gaya Kepemimpinan Kepala Sekolah dan Kinerja Guru. Karena semakin baik gaya kepemimpinan kepala sekolah semakin meningkat pula kinerja guru.

Pengaruh Motivasi Kerja terhadap Kinerja Guru Memperoleh hasil analisis data yang di lakukan secara parsial menunjukkan bahwa terdapat pengaruh antara Motivasi Kerja (X2) terhadap kinerja guru(Y) dapat di simpulkan bahwa motivasi kerja guru berpengaruh secara positif terhadap kinerja guru, apabila tingkat motivasi kerja guru mengalami kenaikan maka kinerja guru di MA Ma arif selorejo juga mengalami kenaikan, begitu pula sebaliknya apabila motivasi kerja guru menurun maka kinerja guru di MA Ma'arif Selorejo menurun.

Pengaruh Gaya Kepemimpinan Kepala Sekolah dan Motivasi Kerja Terhadap Kinerja Guru di MA MA'ARIF Selorejo Blitar Memperoleh hasil Kinerja guru di pengaruhi oleh faktor gaya kepemimpinan kepala sekolah dan motivasi kerja. Semakin baik gaya kepemimpinan kepala sekolah dan motivasi kerja guru maka akan semakin baik pula kinerja guru.

Kepemimpinan kepala sekolah memiliki Indikator seorang pemimpin yang demokratis yaitu pemimpin bersama-sama guru berperan aktif dalam perumusan dan penetapan peraturan secara umum dan keputusan-keputusan penting dalam sekolah Pemimpin, selalu berupaya menghargai potensi setiap individu, Para anggota bebas untuk bekerja dengan siapa yang mereka kehendaki tanpa membatasi kreativitas yang dilakukan oleh bawahannya, dari indikator tersebut maka pemimpin yang demokratis menyadari bahwa dirinya merupakan bagian dari kelompok, memiliki sifat terbuka, dan memberikan kesempatan kepada para tenaga kependidikan untuk ikut berperan aktif dalam membuat perencanan, keputusan, serta menilai kinerjanya. Kepala sekolah yang demokratis memerankan diri sebagai pembimbing, pengarah, pemberi petunjuk, serta bantuan kepada para tenaga pendidikan. Oleh karena itu dalam rapat sekolah, kepala sekolah ikut melibatkan diri secara langsung dan membuka interaksi dengan tenaga pendidikan, serta mengikuti berbagai kegiatan rapat sekolah. Sehingga dengan kepemimpinan yang demokratis tersebut membawa pengaruh yang lebih besar dan signifikan terhadap kinerja guru, diharapkan dengan sistem kepemimpinan yang demokratis dapat dijadikan acuan dalam menjalankan kepemimpinan sebagai kepala sekolah di MA Ma'arif Selorejo.

Motivasi kerja guru merupakan aktivitas yang bisa menimbulkan dorongan pada diri seseorang guru agar bertindak dan melakukan sesuatu tindakan bekerja, dimana seseorang guru yang mempunyai motivasi kerja tinggi akan berusaha melaksanakan tugasnya dengan sekuat tenaga agar pekerjaannya berhasil. Indikator motivasi kerja meliputi faktor intrinsik yaitu Keinginan untuk berprestasi dalam bekerja, Keinginan untuk maju dalam bekerja berupa keinginan untuk memperoleh kehidupan yang lebih baik, 
Baihaqi, I. Muhammad. 2015. Pengaruh Gaya Kepemimpinan Kepala Sekolah dan Motivasi Kerja Terhadap Kinerja Guru di MA Ma'arif Selorejo Blitar. Konstruktivisme, 7(2): 97-106.

Hasil Analisis Regresi Berganda yaitu berdasarkan uji asumsi klasik diatas maka data dalam penelitian ini berdistribusi normal, kemudian model regresinya berbentuk linier, tidak terjadi multikolinieritas (tidak terjadi korelasi antar variabel bebas) tidak terdapat masalah autokorelasi dan tidak terdapat heteroskedastisitas. Hal ini dapat disimpulkan bahwa uji regresi linier berganda dapat digunakan dalam penelitian ini. Model pengujian melalui regresi linier berganda dilakukan untuk melihat pengaruh kepemimpinan kepala sekolah (X1), motivasi kerja guru (X2),terhadap kinerja Guru $(Y)$ baik secara simultan maupun secara parsial. Berdasarkan hasil perhitungan dapat diketahui nilai:

$\mathrm{B}=44,235, \mathrm{~b}_{1}=1,387$, dan $\mathrm{b}_{2}=1,450$ maka dapat disusun persamaan regresi linier berganda sebagai berikut:

$$
\begin{aligned}
& Y=B+b_{1} X_{1}+b_{2} X_{2}+e \\
& Y=44,235+1,387 X_{1}+1,450 X_{2}+e
\end{aligned}
$$

Persamaan tersebut dapat diartikan: 1) Konstanta sebesar 44,235 berarti nilai tersebut didapat apabila tidak ada variabel, $X_{1}$, dan $X_{2}$ atau jika variabel $X_{1}$, dan $X_{2}$ bernilai nol, maka nilai variabel dependen $(Y)$ akan sebesar 44,235. 2) Variabel dependen $(Y)$ berpengaruh dengan variabel $X_{1}$ (kepemimpinan kepala sekolah) sebesar 1,387. Artinya setiap kenaikan variabel $X_{1}$ sebesar 1 satuan, maka variabel $Y$ (kinerja guru) akan naik sebesar 1,387 satuan. 3) Variabel dependen $(Y)$ berengaruh dengan variabel $X_{2}$ (motivasi kerja guru) sebesar 1,450. Artinya, setiap kenaikan variabel $X_{2}$ sebesar 1 satuan, maka variabel $Y$ (kinerja guru) akan naik sebesar 1,450 satuan.

Setelah melihat hasil analisis tersebut maka dapat diketahui variabel bebas (independen) berpengaruh dengan variabel terikat (dependen). Pengaruh variabel bebas dapat dilihat berdasarkan ketepatannya (nilai yang paling signifikan) dari masing-masing variabel bebas, jadi variabel motivasi kerja $\left(\mathrm{X}_{2}\right)$ memiliki pengaruh yang besar terhadap kinerja guru $(Y)$ karena nilai $X_{2}$ koefisien determinasinya lebih besar daripada kepemimpinan kepala sekolah $\left(X_{1}\right)$ dan motivasi kerja $\left(X_{2}\right)$.

Uji $\mathrm{t}$ digunakan untuk menguji kebenaran hipotesis penelitian dilakukan dengan alat penguji signifikan t-test. Pengujian t-tes dimaksutkan untuk menguji signifikansi pengaruh secara sendiri-sendiri (parsial) variabel kepemimpinan kepala sekolah $\left(X_{1}\right)$, motivasi kerja $\left(X_{2}\right)$, terhadap kinerja guru (Y). Penjabaran temuan: H1: Pengambilan terhadap keputusan untuk pengujian hipotesis yag pertama diajukan adalah berdasarkan tabel 4.7 di atas.

Nilai t-hitung untuk variabel $\mathrm{X}_{1}$ (kepemimpinan kepala sekolah) sebesar 2,858 dengan tingkat signifikannya 0,007, karena tingkat signifikannya kurang dari 0,05 maka $X_{1}$ (kepemimpinan kepala sekolah) berpengaruh signifikan dengan variabel $Y$ (kinerja) sehingga $\mathrm{Ha}_{1}$ diterima dan $\mathrm{Ho}_{1}$ ditolak. $\mathrm{H} 2$ : Pengujian hipotesis yang kedua diajukan adalah nilai t-hitung untuk variabel $\mathrm{X}_{2}$ (motivasi kerja guru) sebesar 3,160 dengan tingkat signifikan 0,003 , karena tingkat signifikannya kurang dari 0,05 maka 
$\mathrm{X}_{2}$ (motivasi kerja guru) berpengaruh signifikan dengan variabel $\mathrm{Y}$ (kinerja guru) sehingga $\mathrm{Ha}_{2}$ diterima dan $\mathrm{Ho}_{2}$ ditolak.

Uji $F$ digunakan untuk menggunakan pengaruh secara simultan antara variabel kepemimpinan kepala sekolah $\left(X_{1}\right)$, motivasi kerja guru $\left(\mathrm{X}_{2}\right)$, terhadap kinerja guru $(\mathrm{Y})$. H3: Berdasarkan pada hasil uji data yang diolah dapat diketahui nilai $F$ hitung sebesar 8,484 dengan tingkat signifikansi $0,002<0,05$ atau lebih kecil dari 0,05, maka dapat dikatakan bahwa variabel kepemimpinan kepala sekolah $\left(\mathrm{X}_{1}\right)$, motivasi kerja $\left(\mathrm{X}_{2}\right)$, memiliki pengaruh secara simultan atau bersama-sama terhadap kinerja guru (Y).

Pemberian tanggung jawab (responsibility) pada pekerjaannya. Faktor ekstrinsik meliputi Pekerjaan guru tersebut (rasa bangga), Lingkungan kerja yang kondusif, Keamanan, Jumlah gaji atau penghasilan yang diperoleh, Pengakuan dan penghargaan baik dari pemimpin maupun pemerintah, Kepercayaan diri untuk melakukan pekerjaan, Kebijakan pimpinan. Diharapkan Peningkatan terhadap kinerja guru di sekolah dapat lakukan oleh guru yaitu melalui motivasi yang di milikinya, baik dari faktor intern dan faktor ektern. Setelah melihat hasil analisa di atas tentang kepemimpinan kepala sekolah, motivasi kerja, dan kinerja guru dapat di simpulkan bahwa ketiganya saling berpengaruh dan mendukung kemajuan lembaga MA Ma' arif.

\section{SIMPULAN}

Kesimpulan dari penelitian ini adalah: 1) Terdapat pengaruh yang signifikan kepemimpinan kepala sekolah terhadap kinerja guru di MA MA'Arif Selorejo Blitar 2) Terdapat pengaruh yang signifikan antara motivasi kerja guru terhadap kinerja guru di MA MA'ARIF Selorejo Blitar. 3) Terdapat pengaruh yang signifikan antara kepemimpinan kepala sekolah dan motivasi kerja guru terhadap kinerja guru di MA MA'ARIF Selorejo Blitar

Berdasarkan hasil penelitian ini, maka saran-saran yang dianjurkan adalah sebagai berikut: 1) Bagi Kepala Madrasah, penelitian ini bisa di gunakan sebagai referensi untuk dapat mengembangkan mutu warga madrsah ke depannya. 2) Bagi Guru, dapat di gunakan sebagai acuan untuk meningkatkan kinerja guru yang memiliki profesionalisme di dunia pendidikan. 3) Bagi Peneliti lain yang berminat melakukan penelitian dengan topik yang sama diharapkan hasil penelitian ini dapat menjadi salah satu sumber referensi atau rujukan

\section{DAFTAR PUSTAKA}

Afifudin. 2007. Studi Tentang Pengaruh Kepemimpinan Kepala Madrasah, Supervisi Akademik, Dan Budaya Organisasi Terhadap Kinerja Guru Madrasah Aliyah Negeri Di Jawa Barat.

Anggraini Naskawati. 2003. Hubungan Antara Gaya Kepemimpinan Kepala sekolah, Kemampuan Mengajar dan Disiplin kerja guru dengan Prestasi Belajar Siswa Lanjutan Tingkat Pertama Negeri Dikota Mataram NTB 
Baihaqi, I. Muhammad. 2015. Pengaruh Gaya Kepemimpinan Kepala Sekolah dan Motivasi Kerja Terhadap Kinerja Guru di MA Ma'arif Selorejo Blitar. Konstruktivisme, 7(2): 97-106.

Apuanur .2010. Pengaruh Gaya Kepemimpinan Kepala Sekolah Dan Pemberian Motivasi Terhadap Kinerja Guru(Study Terhadap Persepsi Guru SMPN 2 Sampit. Tesis. Universitas Kanjuruhan Malang

Hasan, M. lqbal. 2002. Pokok-pokok Metodologi Penelitian dan Aplikasinya. Jakarta: Ghalia Indonesia

Hendiyat, Suetopo dan Wasty Suemanto. 1984. Kepemimpinan dan Supervisi Pendidikan. Malang: Bina Aksara

Hermanto, Didik Bambang. 2011. Korelasi Gaya Kepemimpinan Dan Motivasi Kerja Kepala Sekolah Terhadap Kinerja Guru(Studi Tentang Persepsi Guru Sekolah Dasar Kecamatan Siahung Kabupaten Ponorogo). Tesis. Universitas Kanjuruhan Malang

Karmidi. 2003. Kontribusi Iklim Organisasi dan Motivasi Kerja Guru terhadap Kinerja Guru SMU Negeri di Kota Malang. Tesis. Universitas Kanjuruhan Malang.

Mustaqim dan Abdul Wahib, 2001, Psikologi Pendidikan, Jakarta: Renika Cipta,

Meeta. Gaya Kepemimpinan.

http://meetabied.wordpress.com/2009/12/24/gaya-

kepemimpinan/ diakses pada tanggal 20 Maret 2015

Nurhayati. B., Faktor-faktor Yang Mempengaruhi Profesionalisme Dan Kinerja Guru Biologi di SMAN Kota Makasar sulawesi selatan. Mimbar pendidikan. No 4/XXV/2006

Nur Kholis, Manejemen berbasis sekolah, teori, model dan aplikasi. Jakarta: Grasindo, 2003. hal: 167

Permendiknas. Undang-undang No. 14 Tahun 2005 tentang Guru dan Dosen. Jakarta: Permendiknas

Robbin, Stephen P. 2005. Prinsip-Prinsip Perilaku Organisasi, Peterj.: Halida \& Dewi Sartika. Jakarta : Erlangga

Sardiman AM, 2001, Interaksi dan Motivasi Belajar Mengajar, Jakarta: Raja Grafindo Persada

Sarwoko, Endi. 2010. Modul Praktikum Statistik SPSS 16 For Windows. Malang: Universitas Kanjuruhan Malang

Sibrromullisi. 2013. Pengaruh antara gaya kepemimpinan Kepala Sekolah Motivasi Kerja,dan lingkungan sekolah terhadap Kinerja Guru di Yayasan Pendidikan Islam Miftahul UlumBanyuanyar Kabupaten Probolinggo. Tesis. Universitas Kanjuruhan Malang.

Simfoni. Damai. Pengujian Asumsi Klasik. https://dawaisimfoni.wordpress.com. Diakses tanggal 28 Maret 2015

Sugiyono. 2010. Metodeologi Penelitian Pendidikan. Bandung: Alfabeta. 2013, Statistik Untuk Penelitian, Bandung: CV. Alfabeta, 2012. Metode Penelitian Pendidikan. Bandung: alfabeta

Sulistinah. 2013. Pengaruh Gaya Kepemimpinan dan Kinerja Kepala Sekolah Terhadap Kepuasaan Kerja Guru dan Karyawan SMP 
FKIP Universitas Islam Balitar, Blita

Web: konstruktivisme.unisbablitar.ejournal.web.id

Ma'Arif 01 Kota Pasuruan. Tesis. Universitas Kanjuruhan Malang.

Soetopo,Hendyat. 2010. Perilaku Organisasi: Teori dan Praktik di Bidang Pendidikan, Bandung: PT Remaja Rosdakarya

Thoha, Miftah. 2002. Perilaku Organisasi; Konsep Dasar dan Aplikasinya. Jakarta: PT. RajaGrafindo Persada

Tim penyusun PKG. Penilaian Kinerja Guru (PKG).2015.Blitar: Kemenag Kabupaten Blitar

Universitas Kanjuruhan Malang. 2005. Pedoman Penulisan Tesis. Malang Uno,Hamzah B. 2008. Teori Motivasi dan Pengukurannya. Jakarta: PT Bumi Aksara. 